\title{
Molecular Identification and Characterization of Virus Associated with Murda Complex Disease in Chilli (Cv. Byadgi Dabbi)
}

\author{
M. Abdul Kareem* and A.S. Byadgi \\ Department of Plant Pathology, University of Agricultural Sciences, \\ Dharwad - 580 005, Karnataka, India \\ *Corresponding author
}

\section{A B S T R A C T}

\begin{tabular}{|l|}
\hline Ke y w or d s \\
Chilli, Murda \\
complex, Leaf curl, \\
Virus, CVMV, \\
GBNV, ToLCV, \\
TMV, CMV, Byadgi \\
Dabbi.
\end{tabular}

Chilli (Capsicum annuum L.) is an important crop grown worldwide for its use as spice and vegetable. Murda complex is the most destructive syndrome causing substantial economic losses in chilli production. Severe leaf curling, leaf distortion, vein banding, reduced leaf size and stunted growth are typical symptoms of the viral infection. Chilli is known to be infected by many viruses and association of Geminivirus with murda complex is under question as the complex disease doesn't associate with whiteflies. For a reliable identification of virus associated with murda complex disease in chilli (Cv. Byadgi Dabbi), gene specific primer pairs were designed for Potyvirus (CVMV), Geminivirus (ToLCV), Tospovirus (GBNV), TMV and CMV. Upon amplification by PCR using CVMV gene specific primers, $~ 531$ bp size amplicon was amplified in all diseased samples of chilli and no amplification was obtained in healthy samples of chilli. However, no amplification was found with ToLCV, GBNV, TMV and CMV gene specific primer pairs. Thus, the investigation focused on molecular identification, convincingly revealed Chilli veinal mottle virus (Potyvirus) association with the chilli murda complex.

\section{Introduction}

Chilli (Capsicum annuum L.) is an important crop grown worldwide for its use as spice and vegetable. It is an indispensable spice used as basic ingredient in a great variety of cuisines all over the world. Chilli belongs to Capsicum $(2 \mathrm{n}=24)$ a new world genus belonging to Solanaceae family. It is an excellent source of vitamins $\mathrm{C}$, A, B-complex and $\mathrm{E}$. It contains seven times more vitamin $\mathrm{C}$ than orange. Chilli is a fascinating spice, as it has got two important commercial qualities; some varieties are famous for red colour because of the pigment capsanthin, others are known for biting pungency attributed by capsaicin.
India is a major producer, exporter and consumer of chilli. India contributes around 25 per cent of world chilli production. India is the largest producer of chilli crop, which is grown over an area of 7.44 lakh hectares with an annual production of 14.53 lakh tonnes with the productivity of $1953 \mathrm{~kg} / \mathrm{ha}$ (Anon., 2015). The important states growing chilli are Andhra Pradesh, Karnataka, Orissa, Maharashtra, West Bengal, Rajasthan and Tamil Nadu. Karnataka ranks second in area with 1.14 lakh hectares and Production of 1.29 lakh tonnes with the productivity of 1129 $\mathrm{kg} / \mathrm{ha}$ of dry chilli after Andhra Pradesh 
(Anon., 2013). In Karnataka, northern Karnataka is an important chilli growing area and it is highly concentrated in the districts like Dharwad, Gadag, Haveri, Koppal, Bellary, Raichur, Kalaburagi and Belagavi.

India is the only country where many varieties of chilli with different quality factors are grown and it earns tremendous foreign exchange by the export of chilli, oleoresin (of low, medium or high pungency) and chilli powder. Among different chilli cultivars Byadgi, a local land race is the most popular variety known for its mild pungency, fruit colour, aroma, oleoresin content and other characteristics. These properties have made it an exportable produce across the globe. As per the estimates, the export of chilli from India was 3.47 lakh tonnes, which earned a foreign exchange of rupees 3,997 crores (Spices Board of India, 2015-16). There is lot of demand for these chillies both in domestic and international market. Nearly 75 per cent of Byadgi chillies sold in the market are exported in either direct or indirect forms mostly to European, American and Middle East countries. Thus, India earns nearly Rs. 4000 crore worth foreign exchange every year. Hence, there is lot of scope for improving the production and productivity of these chillies in order to expand the export market. Unfortunately, the production potential of Byadgi chilli varieties is very low (700 to $800 \mathrm{~kg} / \mathrm{ha}$ ) as they are highly susceptible to major pests and diseases. Besides lack of high yielding varieties, nonadoption of integrated nutrient and pest management practices by the farmers is also responsible for poor productivity and production in the state.

Chilli suffers from a large number of viral, fungal and bacterial diseases. It is highly susceptible to a large number of viruses through natural and artificial infection. Chilli is known to be affected by 42 viruses. Of these, 22 are found to occur naturally, while the rest are known to infect on artificial infection (Raju, 2010). Chilli leaf curl locally known as murda is a most destructive disease of chilli in India. Murda in chilli is known to be very complex disease caused by agents like thrips, mites and viruses (Puttarudraiah, 1959).

Chilli murda is a complex associated with thrips, mites and virus. Curling of leaves is one of the symptoms of the murda and hence the disease is referred as chilli leaf curl based on symptoms. But the true leaf curl is caused by Geminivirus and spreads through whiteflies. Though chilli is known to be infected by many viruses but association of Geminivirus with murda complex is under question as the complex disease does not associate with whiteflies. Hence, the association of the virus/viruses in the disease complex is not clearly understood.

\section{Materials and Methods}

Leaf samples of chilli plants showing typical symptoms of murda complex (Fig. 1) were collected from open fields UAS campus, Dharwad region of Karnataka, India. Total RNA was isolated from diseased and healthy samples of chilli. Subsequently cDNA was synthesized from the RNA using oligo dT primer and reverse transcriptase enzyme. The cDNA was used as a template for amplification of Potyvirus (CVMV), Tospovirus (GBNV), TMV and CMV using gene specific primers. Similarly, DNA from virus infected and healthy samples of chilli plants was isolated and used as template for amplification of Geminivirus (ToLCV) using gene specific primers.

\section{Characterization of virus coat protein gene}

Cloning of virus coat protein gene (CP) was done in $\mathrm{pTZ57R/T}$ vector by using Inst T/A 
cloning kit. The clone was further confirmed by PCR amplification using gene specific primers and also by restriction analysis using restriction enzymes $\mathrm{Xba}$ I and $\mathrm{Bam} \mathrm{HI}$.

The clone carrying the gene was sequenced using $\mathrm{M} 13 \mathrm{~F} / \mathrm{R}$ primers employing primer walking technique at Merck Specialties Private Ltd., Bangalore. Thus obtained sequences were subjected to analysis using BLAST algorithm available at http://www.ncbi.nlm.nih.gov.

\section{Results and Discussion}

\section{PCR analysis of murda complex infected chilli plants for Potyvirus (CVMV)}

A set of specific primers were designed to amplify the coat protein gene of Potyvirus (CVMV). Upon amplification by PCR, 531 bp size amplicon was amplified in all diseased samples of chilli and no amplification was obtained in healthy samples of chilli. It was clear from the results that the Potyvirus (CVMV) is associated with chilli murda complex (Fig. 2).

This finding is in agreement with Ravi et al., (1997) who compared the N-terminal sequence of PVBV CP with all the potyviral $\mathrm{CP}$ sequences and observed the DAG sequence conserved in all aphid-transmitted Potyviruses in the N-terminal sequence of the PVBV CP. Similar observations of conserved DAG motif was also made by Tsai et al., (2008) in all ChiVMV isolates including Indian isolate. Vector-virus relationship revealed that among the insects, only aphids, Aphis gossypii and Myzus persicae were able to transmit the virus from diseased to healthy chilli seedlings and virus was identified as Potyvirus. However, thrips, mites and whitefly failed to transmit the virus from diseased to healthy seedlings (Gundannavar, 2006). Chilli veinal mottle virus (CVMV) is the most important virus of chilli pepper throughout the country (Krishnareddy et al., 2004).

Supporting to the above study, three left over chilli fields (previously infected with murda complex) with bare stems and free from sucking pests giving new flushes showed systemic dark green mottle, vein banding, necrotic ringspots, leaf distortion and reduced leaf size alone in all leaves. When these leaves diagnosed for CVMV through RT-PCR using the same above degenerate primers, all samples showed fairly a thick amplicon of the predicted size $(1.2 \mathrm{kbp})$, which implicits that the virus remained in its native form in stems and systemically infected the new flush (Pradeep, 2011).

\section{PCR analysis of murda complex infected chilli plants for Geminivirus (ToLCV)}

Upon amplification by PCR, 1000 bp size amplicon was obtained in ToLCV infected Tomato and Ageratum samples. But, the same sized band was missing in chilli samples showing typical symptoms of murda complex disease on several repeats of the experiment. It was clear from the results that no specific association of Geminivirus (ToLCV) is involved with the chilli murda complex (Fig. 3).

This finding is not in agreement with Khan et al., (2006); Senanayake et al., (2007); and Shafiq et al., (2010) who reported Tomato leaf curl New Delhi virus, Chilli leaf curl virus and Pepper leaf curl Lahore virus are the viruses accountable for chilli leaf curl in India. The facts with the disagreement are mentioned below,

In North India the incidence of whitefly in chilli crop starts in the month of July and continues up to fourth week of November. Hence, the presence of whitefly vector 
population throughout the crop period resulting in occurrence of Geminivirus. Whereas in parts of North Karnataka the incidence of whitefly in chilli crop starts from third week of September which results in nonoccurrence of Geminivirus. These findings are confirmed with the results obtained by Arti et

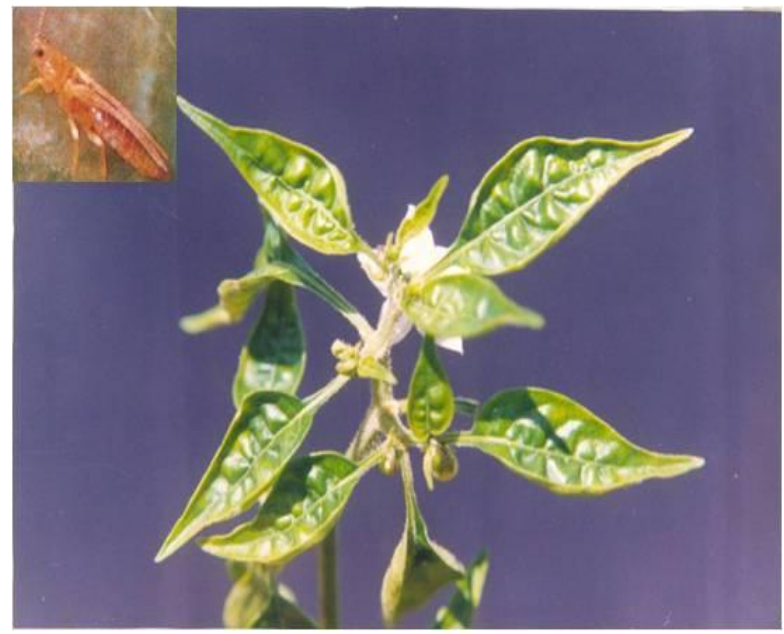

A. Upward Curling

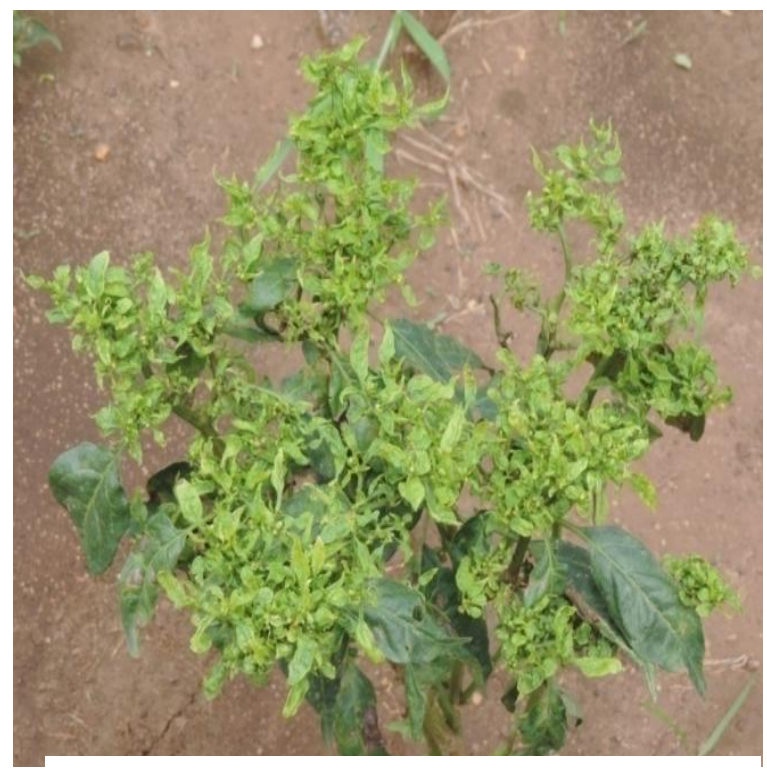

C. Stunting, reduced leaf size and leaf distortion al., (2017) and Meena et al., (2013) from Rajasthan College of Agriculture, Udaipur, who reported that the incidence of whitefly (Bemisia tabaci) commenced in last week of July and touched its peak in second week of September and continue up to fourth week of November.

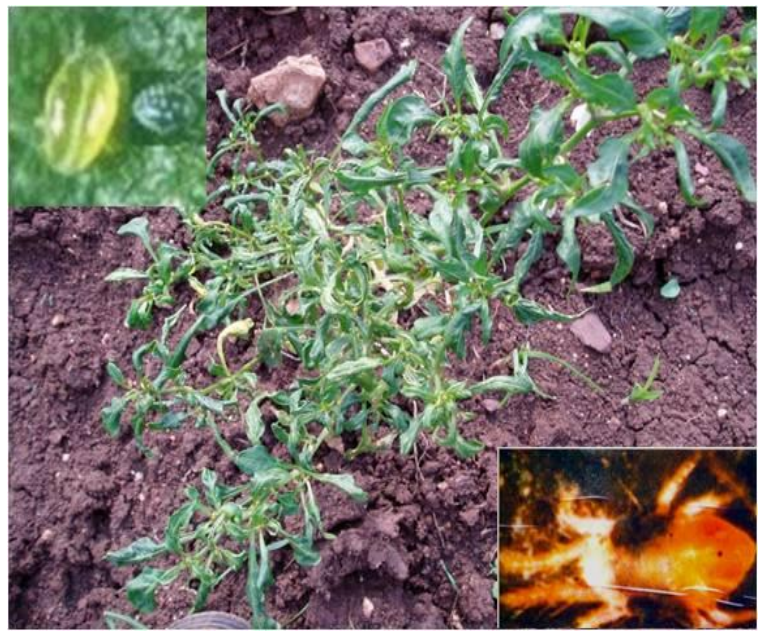

B. Downward curling and petiole elongation

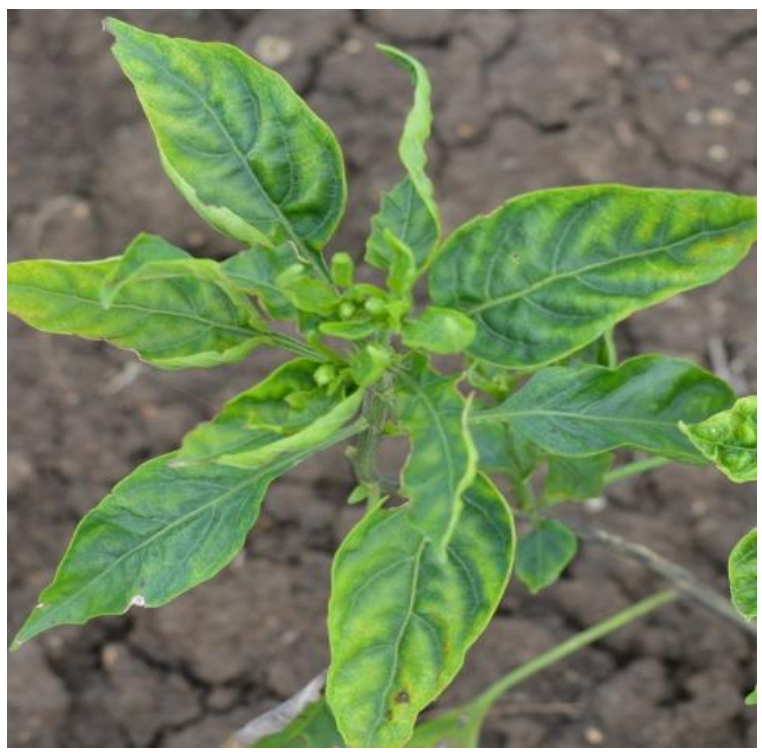

D. Vein banding

Fig.1 'lypical symptoms of murda complex in chilli (Cv. Byadgi Dabbi) 


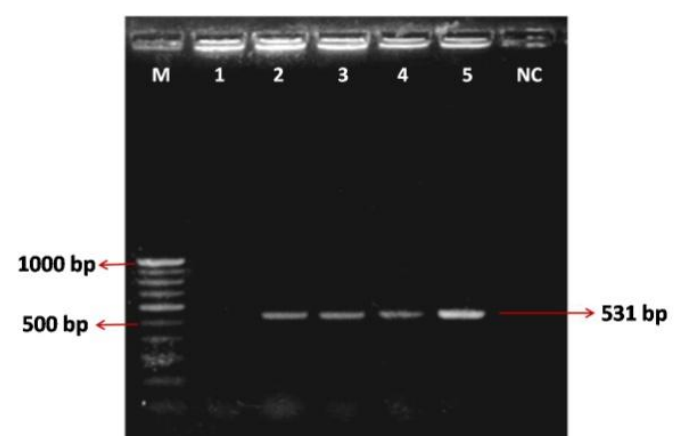

Lane M: 100 bp ladder, Lane 1: Healthy chilli sample,

Lane 2-5: Diseased chilli sample and Lane NC: No template control

Fig.2 PCR analysis of murda complex infected chilli plants for CVMV

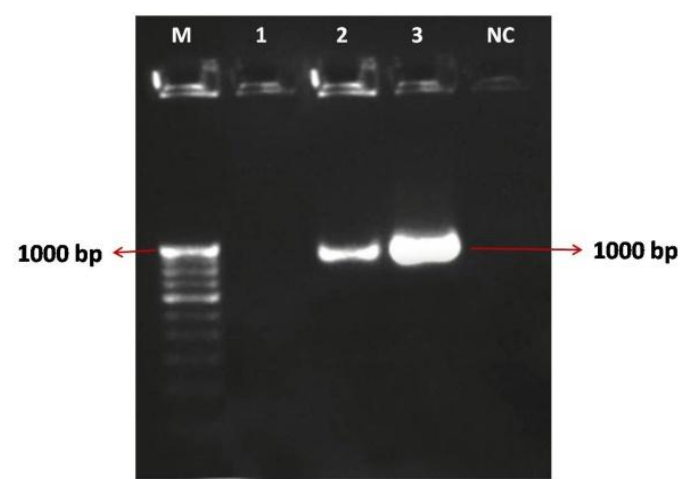

Lane M: 100 bp ladder, Lane 1: Diseased chilli sample, Lane 2: Diseased tomato sample, Lane 3: Diseased ageratum sample and Lane NC: No template control

Fig.3 PCR analysis of murda complex infected chilli plants for ToLCV

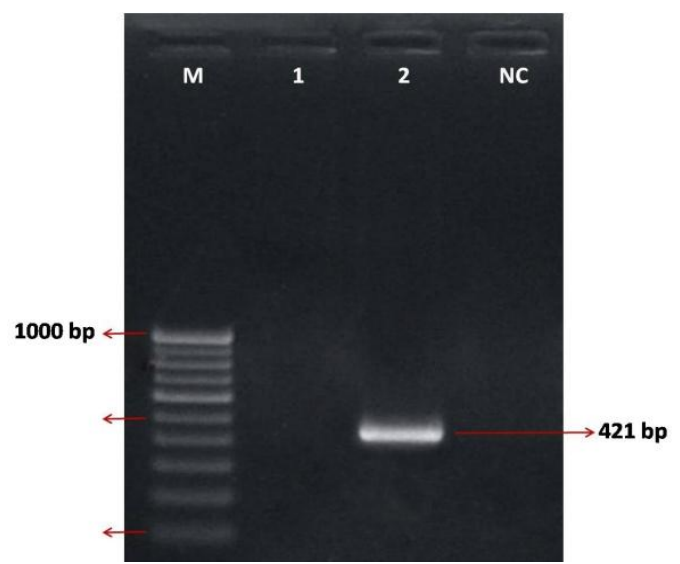

Lane M: 100 bp ladder, Lane 1: Diseased chilli sample, Lane 2: Diseased tobacco sample and Lane NC: No template control

Fig.5 PCR analysis of murda complex infected chilli plants for TMV

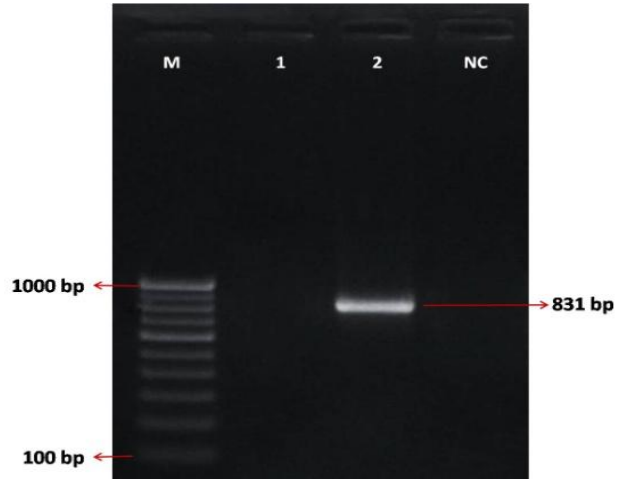

Lane M: 100 bp ladder, Lane 1: Diseased chilli sample, Lane 2: Diseased ground nut sample and Lane NC: No template control

Fig.4 PCR analysis of murda complex infected chilli plants for GBNV

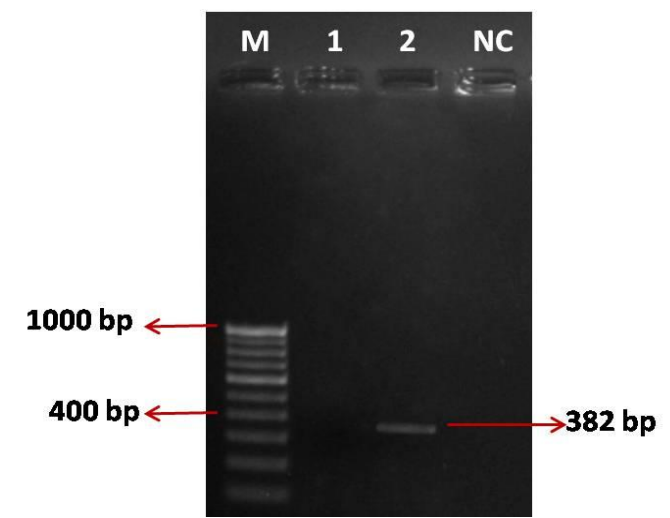

Lane M: 100 bp ladder, Lane 1: Diseased chilli sample, Lane 2: Diseased banana sample and Lane NC: No template control

Fig.6 PCR analysis of murda complex infected chilli plants for $\mathrm{CMV}$ 
The primers designed and used

\begin{tabular}{|c|c|c|c|c|}
\hline $\begin{array}{l}\text { Sl. } \\
\text { No. }\end{array}$ & Virus & & Primer Sequence & $\begin{array}{c}\text { Annealing } \\
\text { Temperature }\end{array}$ \\
\hline \multirow{2}{*}{1.} & \multirow{2}{*}{$\begin{array}{l}\text { Potyvirus } \\
\text { (CVMV) }\end{array}$} & $\mathrm{F}$ & AGCATGGAGAGAGCGACATT & \multirow{2}{*}{61} \\
\hline & & $\mathrm{R}$ & TGGTGACGTTCCATTCTCAA & \\
\hline \multirow{2}{*}{2.} & \multirow{2}{*}{$\begin{array}{l}\text { Geminivirus } \\
\text { (ToLCV) }\end{array}$} & $\mathrm{F}$ & AGGGATTGCATTGGGGTTGTTAG & \multirow{2}{*}{52} \\
\hline & & $\mathrm{R}$ & GCGATACACAAATGCTTCCTGGAC & \\
\hline \multirow{2}{*}{3.} & \multirow{2}{*}{$\begin{array}{l}\text { Tospovirus } \\
\text { (GBNV) }\end{array}$} & $\mathrm{F}$ & ATGTCTAMCGTYAAGCAVCTHAMCG & \multirow{2}{*}{52} \\
\hline & & $\mathrm{R}$ & TTACAMTTCCARMGAAGKRCHAG & \\
\hline \multirow{2}{*}{4.} & \multirow{2}{*}{ TMV } & $\mathrm{F}$ & GACCTGACAAAAATGGAGAAGATCT & \multirow{2}{*}{61} \\
\hline & & $\mathrm{R}$ & GAAAGCGGACAGAAACCCGCTG & \\
\hline \multirow{2}{*}{5 . } & \multirow{2}{*}{$\mathrm{CMV}$} & $\mathrm{F}$ & ACCGCGGGTCTTATTATGGT & \multirow{2}{*}{57} \\
\hline & & $\mathrm{R}$ & ACGGATTCAAACTGGGAGCA & \\
\hline
\end{tabular}

The symptoms observed on chilli in North India are upward curling, puckering, vein clearing, reduced size of leaves, stunting, veinal distortion and swelling of veins and veinlets. Whereas in South India especially in North Karnataka the symptoms observed are systemic dark green mottle, vein banding, reduced leaf size and distortion, fewer and smaller fruits. These findings are confirmed with the results obtained by Senanayake et al., (2007) who reported the characteristic field symptoms of Geminivirus are upward curling, puckering, vein clearing, reduced size of leaves and stunting. Severely affected plants were stunted and produced no fruit. The virus from field samples from Narwa village (Jodhpur district of Rajasthan) was transmitted by whitefly (Bemisia tabaci) to $50-100 \%$ of chilli test plants.

Moreover, there are no reports of above mentioned isolates or strains of viruses on chilli in Southern India as whole. Therefore, these findings reveal Geminivirus existence is missing in the causative agents group that produce murda complex in Byadgi chilli.

Conclusively, chilli leaf curl produced by Geminivirus reported by several workers in Northern parts of India is different from murda syndrome observed locally in South
India especially in Northern parts of Karnataka.

PCR analysis of murda complex infected chilli plants for Tospovirus (GBNV)

Upon amplification by PCR, 831 bp size amplicon was obtained in GBNV infected groundnut sample. No amplification was found both in diseased and healthy chilli samples. It was clear from the results that no specific association of Tospovirus (GBNV) is involved with the chilli murda complex (Fig. 4).

\section{PCR analysis of murda complex infected chilli plants for TMV}

Upon amplification by PCR, 421 bp size amplicon was obtained in TMV infected tobacco sample. No amplification was found both in diseased and healthy chilli samples. It was clear from the results that no specific association of TMV is involved with the chilli murda complex (Fig. 5).

PCR analysis of murda complex infected chilli plants for CMV

Upon amplification by PCR, 2382 bp size amplicon was obtained in CMV infected 
banana sample. No amplification was found both in diseased and healthy chilli samples. It was clear from the results that no specific association of CMV is involved with the chilli murda complex (Fig. 6).

\section{PCR based cloning}

The $\sim 531 \mathrm{bp}$ amplicon of CVMV-CP was eluted from preparative gels. pTZ57R/T (2886 kb) was used as cloning vector for cloning the amplified fragments. E. coli $\mathrm{DH} 5 \alpha$ was transformed separately with molecules using $5 \mu \mathrm{l}$ of ligation mixture. Plasmid DNA of pTZ57R/T was used as positive control.

The transformed cells were screened for blue/white assay to identify the recombinants carrying the coat protein gene.

The colonies that appeared white on Luria agar containing Amp Amo $_{10}$ X-gal and IPTG (Isopropyl b-D-thiogalactoside) are recombinants and the colonies that appeared blue in colour are non- recombinants.

The transformed $E$. coli $\mathrm{DH} 5 \alpha$ clones with pTZ57R/T vector carrying CVMV-CP were initially confirmed by colony PCR using gene specific primers and further confirmed by restriction analysis using Xba I and Bam HI. The recombinant clones of $E$. coli $\mathrm{DH} 5 \alpha$ with pTZ57R/T vector carrying CVMV-CP were named as pTAB531.

The CVMV-CP gene cloned in pTZ57R/T (pTAB531) was sequenced using M13F/R primers at Merck Biosciences Pvt. Ltd, Bangalore. These sequences were subjected to homology search analysis using BLASTn and BLASTp algorithms available at http:// www.ncbi.nlm.nih.gov. The homology search revealed that $\mathrm{CVMV}-\mathrm{CP}$ gene sequence showed maximum homology of 95 per cent with the reported nucleotide sequences from
Aurangabad,

Maharashtra, India (EF213675.1).

Thus, the present investigation focused on molecular identification and characterization clearly revealed that Chilli veinal mottle virus is the distinct virus of the genus Potyvirus associated with chilli murda complex. But, the role of Tospovirus (GBNV), Geminivirus (ToLCV), TMV and CMV with murda complex was not realized.

\section{References}

Anonymous, 2013, State Agriculture Profile, Karnataka State Department of Agriculture, Ministry of Agriculture, Govt. of India, India, p.9.

Anonymous, 2015, Pocket Book of Agriculture Statistics, Directorate of Economics and Statistics, Ministry of Agriculture and Farmers Welfare, Govt. of India, p.53.

Arti, S., Ahir, K. C., Rana, B. S. and Ravi, K., 2017, Population dynamics of sucking pests infecting chilli (Capsicum annum L.). J. Entomol. Zool. Studies, 5 (2): 250-252.

Gundannavar K. P., 2006, Vector-virus relationship and development of organic package for management of chilli $(\mathrm{Cv}$. Byadgi) pests. Ph. D. Thesis, Univ. Agric. Sci., Dharwad (India).

Khan, M. S., Raj, S. K. and Singh, R., 2006, First report of Tomato leaf curl New Delhi virus infecting chilli in India. Plant Pathol., 55: 289.

Krishna Reddy, M., Madhavi Reddy, K., Lakshminarayaa Reddy, C. N., Smitha, R. and Jalali, S., 2004, Molecular characterization and genetic variability of Chilli veinal mottle virus and its reaction on chilli pepper genotypes. Proceedings of the XII EUCARPIA Meeting on Genetics and Breeding, pp.171-177. 
Meena, R. S., Ameta, O. P. and Meena, B. L., 2013, Population dynamics of sucking pests and their correlation with weather parameters in chilli, Capsicum annum L. Crop. The Bioscan, 8 (1): 177-180.

Pradeep, M., 2011, Molecular characterization of virus associated with chilli (Capsicum annuum L.) murda complex. M. Sc. (Agri.) Thesis, Univ. Agric. Sci., Dharwad (India).

Puttarudraiah, M., 1959, Short review on the leaf curl complex and spray programme for its control. Mysore J. Agric. Sci., 34: 93-95.

Raju, S. G., 2010, Studies on chilli leaf curl complex disease. Ph. D. Thesis, Univ. Agric. Sci., Dharwad (India).

Ravi, K. S., Joseph, J., Nagaraju, N., Krishna Prasad, S., Reddy, H. R., and Savithri, H. S., 1997, Characterization of a
Pepper vein banding virus from chilli pepper in India. Plant Dis., 81: 673-676. Senanayake, D. M. J. B., Mandal, B., Lodha, S. and Varma, A., 2007, First report of Chilli leaf curl virus affecting chilli in India. Plant Pathol., 56 (2): 343.

Shafiq Muhammad, Shaheen Asad, Yusuf Zafar, Rob, W., Briddon and Shahid Mansoor, 2010, Pepper leaf curl Lahore virus requires the DNA B component of Tomato leaf curl New Delhi virus to cause leaf curl symptoms. Virol. J., 7: 367.

Tsai, W. S., Huang, Y. C., Zhang, D. Y., Reddy, K., Hidayat, S. H., Srithongchai, W., Green, S. K. and Jan, F. J., 2008, Molecular characterization of the $\mathrm{CP}$ gene and 31UTR of Chilli veinol mottle virus from south and southeast Asia. Plant Pathol, 57: 408-416.

\section{How to cite this article:}

Abdul Kareem, M. and Byadgi, A.S. 2017. Molecular Identification and Characterization of Virus Associated with Murda Complex Disease in Chilli (Cv. Byadgi Dabbi). Int.J.Curr.Microbiol.App.Sci. 6(11): 2837-2844. doi: https://doi.org/10.20546/ijcmas.2017.611.335 